\title{
Milk Yield and Composition As Affected by Nutritional Manipulations
}

\author{
Samir A. Najadi, H. M. Baakeel and E. A. Elwakeel* \\ Department of Arid Land Agriculture, Faculty of Meteorology, Environment and Arid Land \\ Agriculture, King Abdulaziz University, Jeddah, Saudi Arabia, \\ *Department of Animal and Fish Production, Faculty of Agriculture, Alexandria University, \\ Alexandria, Egypt \\ *Corresponding author: elwakeel@yahoo.com
}

\begin{abstract}
The objective was to evaluate milk yield, milk composition and milk fatty acids contents of lactating Harri ewes $(n=24)$ receiving different concentrate to roughage (A 80:20; B 60:40; C 40:60 and D 20:80 C:R) rations. The results revealed that no differences $(P=0.29)$ in body weights of ewes were detected after parturition but body weights declined steadily as ewes continued on lactation. Group D produced more $(P<0.01)$ milk $(1.38 \pm 0.5 \mathrm{~kg} /$ day $)$ than groups A $(0.76 \pm 0.5 \mathrm{~kg} /$ day $), \mathrm{B}(0.88 \pm 0.5 \mathrm{~kg} / \mathrm{day})$ and $\mathrm{C}(0.66 \pm 0.5$ $\mathrm{kg} /$ day). Yields of milk fat, SNF, protein, lactose and minerals yields $(\mathrm{g} /$ day) were greater $(P=0.01)$ in group $\mathrm{D}$ than groups $\mathrm{B}$ and $\mathrm{C}$ not group A. No differences were found in milk fat, SNF, protein, lactose and minerals percentages (\%). Groups D and A had more $(P=0.06) \mathrm{C} 18: 2 \mathrm{c}(3.15 \pm 0.21$ and $2.99 \pm 0.08 \mathrm{~g} / 100 \mathrm{~g}$ fat $)$ than group B $(1.98 \pm 0.54 \mathrm{~g} / 100 \mathrm{~g}$ fat) not group C $(2.72 \pm 0.05 \mathrm{~g} / 100 \mathrm{~g}$ fat). Poly unsaturated fatty acids (PUFA) were increased $(P<0.01)$ in groups $\mathrm{A}$ and D $(4.07 \pm 0.18$ and $4.49 \pm 0.27 \mathrm{~g} / 100 \mathrm{~g}$ fat $)$ than groups B and $\mathrm{C}$ $(3.34 \pm 0.12$ and $3.41 \pm 0.23 \mathrm{~g} / 100 \mathrm{~g}$ fat $)$. Lactating ewes' diet should include adequate ratio of roughage to increase milk yield and improve milk fat composition of unsaturated fatty acids.
\end{abstract}

Keyword: Sheep, concentrate: roughage ratio, nutrition, milk yield, fatty acids.

\section{Introduction}

Breeding of sheep for dairy purposes has a long tradition throughout the world. Sheep milk accounts for only $2 \%$ of the global volume of milk obtained, but in some countries, such as Yemen, this proportion reaches as much as 50 or $90 \%$ (Molik et al., 2008). The physico-chemical characteristics of sheep milk have unique properties as compared to goat and cow milk. Sheep milk contains higher levels of total solids and major nutrients than goat and cow milk. Also, mineral and vitamin contents of sheep milk are mostly higher than that of cow milk (Park et al., 2007). Sheep milk is more nutritious, richer in vitamins $\mathrm{A}, \mathrm{B}$ and $\mathrm{E}$, calcium, phosphorus, potassium and magnesium than cow milk (Coni et al., 1999). Also, it contains a higher portion of short and medium chain 
fatty acids, which have a recognized health benefits (Jandal, 1996). The optimal roughage concentration required in feedlot diets changes continuously for many reasons such as source, availability, price, and interaction with other ingredients in the diet. It has been established for many years that replacement of most of the roughage of mixed diets by starchy concentrates results in an alteration in energy partition between body and milk and a reduced milk fat content (Broster, et al 1979).

The aim of this study was to evaluate the effect of feeding lactating ewes on rations different in their concentrate and roughage content on body weight, milk yield, milk composition and milk fatty acids content.

\section{Materials and Methods}

The present study was conducted at Hada Al-Sham experimental station, Arid Land Agriculture Department, Faculty of Meteorology, Environment and Arid Land Agriculture King Abdulaziz University, Jeddah, KSA and Animal Nutrition Laboratory, Animal and Fish Production Department, Faculty of Agriculture, Alexandria University. The aim of this study was to evaluate the effect of feeding four rations with different concentrate to roughage $(\mathrm{C}: \mathrm{R})$ ratios on body weight of dams and offspring, milk yield and composition of milk fatty acids in lactating Harri sheep.

\section{Animals and experimental rations}

Twenty four lactating Harri ewes (2 years age and $50 \pm 1.0 \mathrm{~kg}$ body weight) were stratified based on age and live body weight then randomly divided into four groups to receive the following four experimental rations. Group A given $80 \%$ concentrate $+20 \%$ roughage; group $\mathrm{B}$ given $60 \%$ concentrate $+40 \%$ roughage; group $\mathrm{C}$ given $40 \%$ concentrate $+60 \%$ roughage; group $\mathrm{D}$ given $20 \%$ concentrate $+80 \%$ roughage. Concentrate mixture were produced by the Saudi Grains Organization (SAGO), Jeddah, KSA and the roughage was dry alfalfa hay. Animals were fed their daily rations as group feeding which was adjusted weekly according to the NRC recommendations (1985). Ewes were housed in open barns with shades and had free access to fresh water and mineralized blocks. Ewes were healthy and free from any parasites and diseases.

\section{Rations proximate chemical composition}

Experimental rations were offered two times daily at 6:00 AM and 16:00 PM. Experimental rations samples were collected biweekly and dried to determine DM content. The dried samples were ground to pass a 1$\mathrm{mm}$ screen using Wiley mill. Feed analyses were performed according to AOAC (2006). Dry matter contents of feeds were determined by drying at $135^{\circ} \mathrm{C}$ for $2 \mathrm{~h}$. Organic matter was determined as the weight loss during ashing at $550^{\circ} \mathrm{C}$ for $2 \mathrm{~h}$. Contents of nitrogen $(\mathrm{N})$ were determined by the kjeldahl method, and crude protein $(\mathrm{CP})$ was calculated as $6.25 \times \mathrm{N}$. Ether extract was analyzed according to AOAC (2006). The neutral detergent fibers (NDF) and acid detergent fiber (ADF) were determined using the procedures of Van Soest et al. (1991). No sodium sulfite or $\alpha$ - amylase was used in the procedure for NDF determination. Both NDF and ADF are expressed without residual ash.

\section{Milk yield and composition}

Milk production was determined biweekly beginning two weeks after parturition. Milk yield for individual ewes were determined by milking out the ewes by hand. Lambs were removed from their dams and kept in separate pens $20 \mathrm{~h}$ prior to milking process. All lambs born during the experiment were allowed to naturally suckle their mothers for a period of three months before weaning. Lambs were weighed immediately after birth and then body weights were recorded weekly for 12 weeks before weaning. Milk samples were collected biweekly and analyzed immediately for milk fat, protein, lactose, 
minerals and solids non fat (SNF) using the infrared method by milk Analyzer (Funke Gerber Lactostar-3510). A second fresh milk samples were withheld for milk fat extraction. Solvent-extracted milk fat samples were run through gas chromatography (GC) to determine the proportions of saturated and unsaturated fatty acids and their derivatives.

\section{Milk fatty acids analysis}

Lipid extraction:

A 2 to $20 \mathrm{~g}$ of milk samples were weighed into a 250-ml centrifuge bottles; $16 \mathrm{ml}$ of $\mathrm{H}_{2} \mathrm{O}$ was added together with $40 \mathrm{ml}$ methanol and $20 \mathrm{ml}$ chloroform. Bottles were macerated for $2 \mathrm{~min}$ and then $20 \mathrm{ml}$ of chloroform was added and macerated for $30 \mathrm{sec}$ before addition of 20 $\mathrm{ml}$ of $\mathrm{H}_{2} \mathrm{O}$ and maceration for a $30 \mathrm{sec}$. Bottles were centrifuged for $10 \mathrm{~min}$ at 2000-2500 rpm and the upper chloroform layer was drawn off and filtered through a coarse filter paper into a dry weighed flask. Chloroform was evaporated to dryness and extracted amount of fat was recorded (Pearson, 1981).

Methylation of lipid:

A weight of $50 \mathrm{mg}$ of extracted milk fat was added to $5 \mathrm{ml}$ of methanolic sulfuric acid ( $1 \mathrm{ml}$ conc. sulfuric acid and $100 \mathrm{ml}$ methanol) and $2 \mathrm{ml}$ of benzene in a well-closed tube. The tube was incubated in a $90^{\circ} \mathrm{C}$ water bath for 1 hour and half. Water $(8 \mathrm{ml})$ and $5 \mathrm{ml}$ petroleum ether were added to the cooled down tubes then shaken strongly and allowed to rest to separate out the ethereal layer in a dry tube. Ether was then evaporated to dryness (Radwan, 1978).

GC conditions:

Device Model: HP (Hewlett Packard) 6890 GC; Detector: FID (Flame Ionization Detector); Detector temperature: 240oC; Injector temperature: $220 \mathrm{oC}$, injection volume $3 \mu 1$, split ratio 50:1; Column: DB-23 (50\% Cyanopropyl-methylpolysiloxane), $\quad 30 \mathrm{~m}$, $0.32 \mathrm{~mm}$ ID, $0.25 \mu \mathrm{m}$ film thickness; Carrier gas: Nitrogen; Gas flow rate: $1 \mathrm{ml} / \mathrm{min}$; Oven Program: Initial temperature $140^{\circ} \mathrm{C}$ for $5 \mathrm{~min}$;
Ramps: 1; Rate: $4^{\circ} \mathrm{C} / \mathrm{min}$; Final Temperature: $240^{\circ} \mathrm{C}$; Hold time: 0 .

\section{Statistical analysis:}

The fixed effects of treatment, time (sampling or measuring times) and their interactions were analyzed using the PROC GLM procedure of SAS (SAS, 2006) in a complete randomized design (CRD) with treatment and time as main effects and ewe as the experimental unit. The statistical model was: $\mathbf{Y}_{\mathbf{i j k}}=\boldsymbol{\mu}+\mathbf{T r t}_{\mathbf{i}}+\mathbf{T i m e}_{\mathbf{j}}+\mathbf{T r t}_{\mathbf{i}} \times \mathbf{T i m e}_{\mathbf{j}}+$ $\mathbf{e}_{\mathrm{ijk}}$; Where $\mathbf{Y}_{\mathrm{ijk}}=$ the performance of the $\mathrm{k}^{\text {th }}$ ewe in the $\mathrm{i}^{\text {th }}$ treatment during the $\mathrm{j}^{\text {th }}$ time; $\boldsymbol{\mu}=$ the overall mean effect; Trt $_{\mathbf{i}}=$ the effect of the $\mathrm{i}^{\text {th }}$ treatment $(\mathrm{i}=\mathrm{A}, \mathrm{B}, \mathrm{C}, \mathrm{D}) ;$ Time $_{\mathbf{i}}=$ the effect of the $j^{\text {th }}$ time; $\mathbf{T r t}_{\mathbf{i}} \times \mathbf{T i m e}_{\mathbf{j}}=$ interaction between treatment and time; $\mathbf{e}_{\mathbf{i j k}}=$ the random error. Differences among the means were separated by Duncan's multiple range tests. Statistical significance was declared at $P<$ 0.05 .

\section{Results}

\section{Proximate analyses of experimental diets}

\section{$A, B, C$ and $D$ on dry matter basis:}

Values of the proximate analyses on dry matter basis of diets A, B, C and D are presented in Table 1. No differences were found among diets in percentages of organic matter (OM), ash, crude protein (CP) and Ether extract (EE) content. The highest values for NDF and ADF were observed in diet D that had higher content of neutral detergent fiber (NDF, 44.63\%), acid detergent fiber (ADF, 28.20\%), acid detergent lignin (ADL, $7.14 \%)$ and cellulose $(21.06 \%)$ as compared to diet A $(34.75,13.43,3.23$ and $10.19 \%$, respectively). Similar trend was observed in the content of ADL and cellulose (Table 1).

\section{Body weight of Harri ewes and their lambs during lactation:}

Changes in ewes' body weight and their lambs' birth and weaning weight during 
lactation are presented in Table 2 and Figures 1 and 2. No significant $(P=0.29)$ differences in body weights of ewes supplemented with the four experimental rations were detected after parturition. There were no changes among treatment groups in body weights with advancement of lactation but body weights declined steadily as ewes continued on lactation (Figure 1).

Table 1. Mean values of proximate analyses of treatment diets A, B, C and D on dry matter basis.

\begin{tabular}{|c|c|c|c|c|}
\hline \multirow{2}{*}{ Items } & \multicolumn{4}{|c|}{ Treatments } \\
\hline & $\mathrm{A}$ & $\mathrm{B}$ & $\mathrm{C}$ & $\mathrm{D}$ \\
\hline $\mathrm{OM}$ & 92.65 & 91.80 & 91.10 & 90.15 \\
\hline ASh & 7.35 & 8.20 & 8.90 & 9.85 \\
\hline $\mathrm{CP}$ & 19.25 & 17.71 & 20.56 & 20.68 \\
\hline $\mathrm{EE}$ & 5.64 & 5.02 & 4.40 & 5.75 \\
\hline NDF & 34.75 & 38.64 & 41.55 & 44.63 \\
\hline $\mathrm{ADF}$ & 13.43 & 19.51 & 23.41 & 28.20 \\
\hline ADL & 3.23 & 4.31 & 5.30 & 7.14 \\
\hline Hemicellulose & 21.32 & 19.13 & 18.14 & 16.43 \\
\hline Cellulose & 10.19 & 15.20 & 18.11 & 21.06 \\
\hline
\end{tabular}

$A=80: 20 ; B=60: 40 ; C=40: 60 ; D=20: 80(C: R)$, OM: organic matter; $C P$ : crude protein; EE: ether extract; NDF: neutral detergent fiber; ADF: acid detergent fiber; ADL: acid detergent lignin.

Also, no differences in lambs birth $(P=0.99)$ and weaning weights $(P=0.24)$ were recorded. However, lambs born in $\mathrm{D}, \mathrm{C}$ and $\mathrm{B}$ groups had heavier weaning weight by $9.9,6.2$ and $8.7 \%$, respectively as compared to those of group A (Table 2). Overall lambs' body weight increased with advancement of age (week1 - week12) with no differences in lambs' body weight among groups (Figure 2).

Table 2. Body weight of lactating Harri ewes, lambs' birth and weaning weight (kg) (Mean $\pm \mathrm{SE})$.

\begin{tabular}{cccccc}
\hline \multirow{2}{*}{ Item } & \multicolumn{5}{c}{ Treatments } \\
\cline { 2 - 5 } & $\mathrm{A}$ & $\mathrm{B}$ & $\mathrm{C}$ & $\mathrm{D}$ & P-value \\
\hline Body weight of dams & $46.65 \pm 1.1$ & $44.56 \pm 2.0$ & $42.67 \pm 1.3$ & $43.31 \pm 1.3$ & 0.29 \\
Lambs' Birth weight & $2.96 \pm 0.23$ & $2.90 \pm 0.31$ & $2.89 \pm 0.26$ & $2.87 \pm 0.46$ & 0.99 \\
& & & & $19.29 \pm 0.87$ & 0.24 \\
\hline
\end{tabular}

$A=80: 20 ; B=60: 40 ; C=40: 60 ; D=20: 80(C: R)$ 


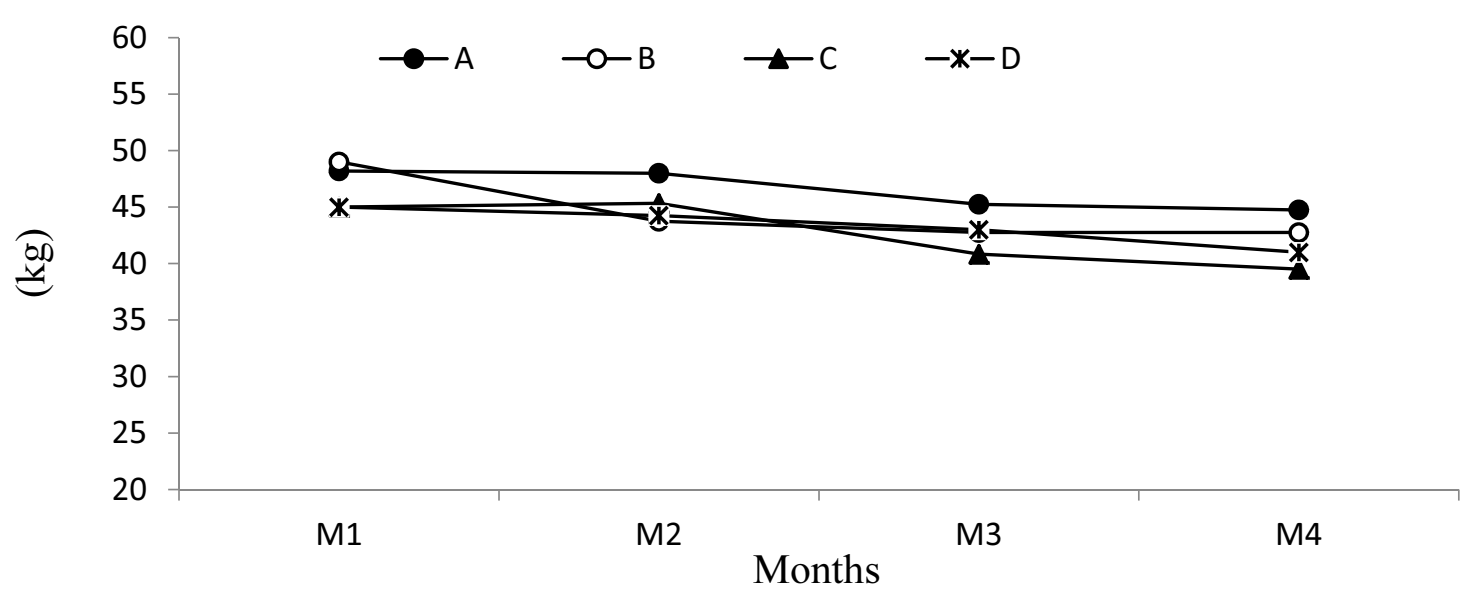

Fig. 1. Monthly changes in body weight $(\mathrm{kg})$ of lactating ewes fed on four experimental rations A (80:20), B (60:40), C (40:60) and $D(20: 80) C: R$.

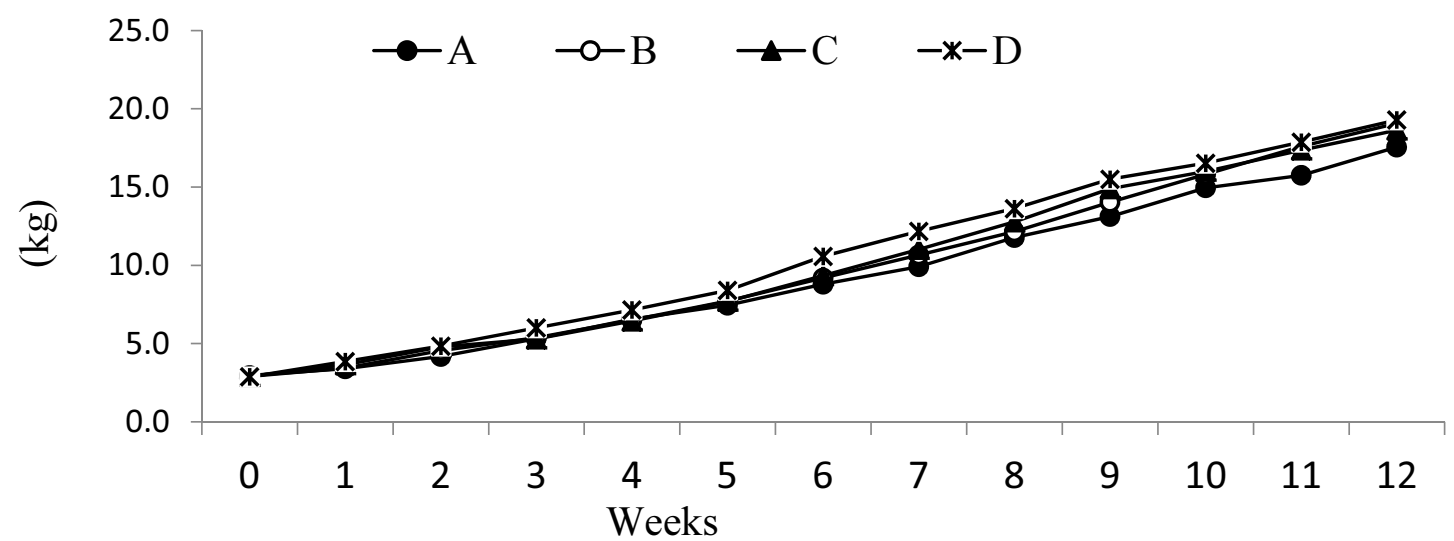

Fig. 2. Weekly changes in lambs body weight (kg) from Harri ewes fed four experimental rations A (80:20), B (60:40), C (40:60) and $D(20: 80) C: R$.

\section{Milk yield and milk composition:}

Milk yield ( $\mathrm{kg} /$ day) and milk composition data for Harri ewes is presented in Table 3. Analysis of milk yield data revealed that ewes fed on the experimental ration $\mathrm{D}$ produced more $(P<0.01)$ daily milk yield $(1.38 \pm 0.5$ $\mathrm{g} /$ day) than ewes fed on experimental rations A $(0.76 \pm 0.5 \mathrm{~g} /$ day $), \mathrm{B}(0.88 \pm 0.5 \mathrm{~g} /$ day $)$ and $\mathrm{C}$ $(0.66 \pm 0.5 \mathrm{~g} /$ day $)$. Milk fat yield (g/day) was greater $(P=0.01)$ in treatment A $(55.6 \pm 20.9$ $\mathrm{g}$ /day) and $\mathrm{D} \quad(58.4 \pm 10.7 \mathrm{~g} /$ day $)$ than treatments B $(16.5 \pm 3.4 \mathrm{~g} /$ day $)$ and C $(21.9 \pm 3.0$ $\mathrm{g} /$ day). Milk SNF yield (g/day) was greater $(\mathrm{P}=0.01)$ in treatment $\mathrm{D}(125.3 \pm 14.9 \mathrm{~g} /$ day $)$ than treatments $\mathrm{B}(61.4 \pm 6.4 \mathrm{~g} /$ day $)$ and $\mathrm{C}$ $(70.9 \pm 6.8 \mathrm{~g} /$ day $)$ not treatment A $(116.1 \pm 30.8$ $\mathrm{g} /$ day). Milk protein yield (g/day) was greater $(\mathrm{P}<0.01)$ in treatment $\mathrm{D}(59.2 \pm 5.4 \mathrm{~g} /$ day $)$ than treatments $\mathrm{B}(28.1 \pm 1.2 \mathrm{~g} /$ day $)$ and $\mathrm{C}$ $(31.3 \pm 2.5 \mathrm{~g} /$ day $)$ not treatment A $(50.6 \pm 12.0$ $\mathrm{g} /$ day). Milk lactose yield (g/day) was greater $(P=0.03)$ in treatment $\mathrm{D}(45.5 \pm 7.4 \mathrm{~g} /$ day $)$ than treatments $\mathrm{B}(20.4 \pm 2.5 \mathrm{~g} /$ day $)$ and $\mathrm{C}$ $(25.8 \pm 2.9 \mathrm{~g} /$ day $)$ not treatments A $(39.8 \pm 11.5$ $\mathrm{g} /$ day). Milk minerals yield (g/day) was greater $(P=0.04)$ in treatment $\mathrm{D}(8.5 \pm 1.3$ $\mathrm{g}$ /day) than treatments B $(3.9 \pm 0.4 \mathrm{~g} /$ day $)$ not treatment A $(6.4 \pm 1.6 \mathrm{~g} /$ day $)$ and $\mathrm{C}(4.8 \pm 0.6$ $\mathrm{g} /$ day). Meanwhile, no significant differences were found in milk fat, SNF, protein, lactose and minerals percentages (\%) among all groups. 
Table 3. Milk fat, solids not fat (SNF), protein, lactose, and minerals yield (g/day) and composition (\%) in Harri ewes fed on four different diets (A, B, C, and D) during lactation.

\begin{tabular}{lccccc}
\hline \multirow{2}{*}{$\begin{array}{l}\text { Yield, } \\
\text { (g/day) }\end{array}$} & \multicolumn{2}{c}{ Treatments } & P-value \\
\cline { 2 - 5 } & $\mathrm{A}$ & $\mathrm{B}$ & $\mathrm{C}$ & $\mathrm{D}$ & $<0.01$ \\
\hline Milk yield, kg/day & $0.76 \pm 0.13^{\mathrm{b}}$ & $0.88 \pm 0.10^{\mathrm{b}}$ & $0.66 \pm 0.06^{\mathrm{b}}$ & $1.38 \pm 0.15^{\mathrm{a}}$ & 0.01 \\
Fat (g/day) & $55.6 \pm 20.9^{\mathrm{a}}$ & $16.5 \pm 3.4^{\mathrm{b}}$ & $21.9 \pm 3.0^{\mathrm{b}}$ & $58.4 \pm 10.7^{\mathrm{a}}$ & 0.11 \\
Fat, \% & $4.80 \pm 0.7$ & $3.36 \pm 0.4$ & $3.31 \pm 0.3$ & $4.26 \pm 0.5$ & 0.01 \\
SNF, (g/day) & $116.1 \pm 30.8^{\mathrm{ab}}$ & $61.4 \pm 6.4^{\mathrm{c}}$ & $70.9 \pm 6.8^{\mathrm{bc}}$ & $125.3 \pm 14.9^{\mathrm{a}}$ & 0.13 \\
SNF, \% & $10.70 \pm 0.3$ & $10.61 \pm 0.2$ & $11.01 \pm 0.3$ & $10.32 \pm 0.1$ & 0.05 \\
Protein, (g/day) & $50.6 \pm 12^{\mathrm{ab}}$ & $28.1 \pm 1.2^{\mathrm{b}}$ & $31.3 \pm 2.5^{\mathrm{b}}$ & $59.2 \pm 5.4^{\mathrm{a}}$ & 0.16 \\
Protein, \% & $3.5 \pm 0.5$ & $3.8 \pm 0.1$ & $4.0 \pm 0.1$ & $3.8 \pm 0.1$ & \\
lactose, (g/day) & $39.8 \pm 11.5^{\mathrm{ab}}$ & $20.4 \pm 2.5^{\mathrm{b}}$ & $25.8 \pm 2.9^{\mathrm{ab}}$ & $45.5 \pm 7.4^{\mathrm{a}}$ & 0.03 \\
Lactose, \% & $4.9 \pm 0.3$ & $4.9 \pm 0.3$ & $4.8 \pm 0.4$ & $4.8 \pm 0.1$ & 0.94 \\
Minerals, (g/day) & $6.4 \pm 1.6^{\mathrm{ab}}$ & $3.9 \pm 0.4^{\mathrm{b}}$ & $4.8 \pm 0.6^{\mathrm{ab}}$ & $8.5 \pm 1.3^{\mathrm{a}}$ & 0.04 \\
Minerals, \% & $0.6 \pm 0.02$ & $0.7 \pm 0.02$ & $0.7 \pm 0.04$ & $0.7 \pm 0.03$ & 0.12 \\
\hline 80:20;B=60:40;C=40:60; $\mathrm{D}=20: 80(\mathrm{C}: \mathrm{R})$ & & &
\end{tabular}

$\mathrm{A}=80: 20 ; \mathrm{B}=60: 40 ; \mathrm{C}=40: 60 ; \mathrm{D}=20: 80(\mathrm{C}: \mathrm{R})$

Table 4. Unsaturated milk fatty acids (g/100g fat) in Harri ewes fed on four different diets (A, B, C, and D) during lactation. (means \pm SE).

\begin{tabular}{|c|c|c|c|c|c|}
\hline \multirow{2}{*}{ Fatty acids } & \multicolumn{4}{|c|}{ Treatments } & \multirow{2}{*}{$\begin{array}{c}P- \\
\text { value }\end{array}$} \\
\hline & A & B & $\mathrm{C}$ & $\mathrm{D}$ & \\
\hline C14:1 & $0.51 \pm 0.38$ & $0.05 \pm 0.05$ & $0.09 \pm 0.09$ & - & 0.27 \\
\hline C15:1 & $0.39 \pm 0.07$ & $0.09 \pm 0.06$ & $0.66 \pm 0.46$ & $0.64 \pm 0.08$ & 0.34 \\
\hline C16:1 & $0.79 \pm 0.09$ & $0.68 \pm 0.09$ & $0.74 \pm 0.05$ & $0.79 \pm 0.08$ & 0.74 \\
\hline $\mathrm{C} 17: 1$ & $0.3 \pm 0.22$ & $0.33 \pm 0.24$ & $0.34 \pm 0.26$ & $0.3 \pm 0.21$ & 0.99 \\
\hline $\mathrm{C} 18: 1 \mathrm{c}$ & $26.7 \pm 0.77$ & $22.38 \pm 0.88$ & $24.49 \pm 0.79$ & $28.03 \pm 2.45$ & 0.81 \\
\hline $\mathrm{C} 18 \mathrm{a} 2 \mathrm{c}$ & $2.99 \pm 0.08^{\mathrm{a}}$ & $1.98 \pm 0.54^{\mathrm{b}}$ & $2.72 \pm 0.05^{\mathrm{ab}}$ & $3.15 \pm 0.21^{\mathrm{a}}$ & 0.06 \\
\hline $\mathrm{C} 18: 2 \mathrm{t}$ & $0.68 \pm 0.14$ & $0.98 \pm 0.43$ & $0.3 \pm 0.17$ & $0.84 \pm 0.15$ & 0.30 \\
\hline $\mathrm{C} 18: 3 \alpha$ & $0.4 \pm 0.05$ & $0.38 \pm 0.01$ & $0.39 \pm 0.04$ & $0.5 \pm 0.03$ & 0.11 \\
\hline MUFA & $28.69 \pm 1.25$ & $23.53 \pm 8.8$ & $26.31 \pm 1.11$ & $29.75 \pm 2.53$ & 0.78 \\
\hline PUFA & $4.07 \pm 0.18^{\mathrm{a}}$ & $3.34 \pm 0.12^{\mathrm{b}}$ & $3.41 \pm 0.23^{\mathrm{b}}$ & $4.49 \pm 0.27^{\mathrm{a}}$ & 0.005 \\
\hline Total USFA & $32.76 \pm 1.37$ & $26.87 \pm 8.92$ & $29.72 \pm 1.18$ & $34.23 \pm 2.61$ & 0.70 \\
\hline
\end{tabular}

$A=80: 20 ; B=60: 40 ; C=40: 60 ; D=20: 80$ (C:R); MUFA: sum of mono unsaturated fatty acids (C14:1, C15:1, C16:1, C17:1, C18:1c); PUFA: sum of poly unsaturated fatty acids (C18:2c, C18:2t; $\mathrm{C} 18: 3 \alpha)$; Total USFA: sum of MUFA+PUFA.

${ }^{a-b}$ Values within same row with different letters differ $(\mathrm{P}<0.05)$ 


\section{Unsaturated fatty acids:}

Percentages of unsaturated fatty acids are presented in Table 4. Experimental diets with different roughage to concentrate ratios $(\mathrm{A}, \mathrm{B}$, $\mathrm{C}$ and $\mathrm{D})$ did not affect the percentages of unsaturated fatty acids (C14:1, C15:1, C16:1, $\mathrm{C} 17: 1 ; \mathrm{C} 18: 1 \mathrm{c}, \mathrm{C} 18: 2 \mathrm{t}$ and $\mathrm{C} 18: 3 \alpha)$ except for the C18:2c fatty acid. Ewes fed on D and A diets had more $(P=0.06) \mathrm{C} 18: 2 \mathrm{c}(3.15 \pm 0.21$ and $2.99 \pm 0.08 \mathrm{~g} / 100 \mathrm{~g}$ fat) than ewes fed on diets B $(1.98 \pm 0.54 \mathrm{~g} / 100 \mathrm{~g}$ fat $)$ not on diet C $(2.72 \pm 0.05 \mathrm{~g} / 100 \mathrm{~g}$ fat $)$. Also, percentages of mono (MUFA)- and total unsaturated fatty acids (Total USFA) were not affected with treatments. However, percentages of poly unsaturated fatty acids (PUFA) were increased $(P<0.01)$ in milk fat from ewes fed on diets A and $\mathrm{D}(4.07 \pm 0.18$ and $4.49 \pm 0.27 \mathrm{~g} / 100 \mathrm{~g}$ fat $)$ compared to diets $\mathrm{B}$ and $\mathrm{C}(3.34 \pm 0.12$ and $3.41 \pm 0.23 \mathrm{~g} / 100 \mathrm{~g}$ fat).

\section{Saturated fatty acids:}

Percentages of saturated fatty acids are presented in Table 5. Percentages of saturated fatty acids (C6:0; C8:0; C10:0; C12:0; C14:0; $\mathrm{C} 15: 0 ; \mathrm{C} 17: 0 ; \mathrm{C} 18: 0$ and $\mathrm{C} 20: 0$ and percentages of total saturated fatty acids (C6:0-C20:0); short chain fatty acids (Short CFA, C6:0- C10:0); medium chain fatty acids (Medium CFA, C12:0 - C15:0) and long chain fatty acids (Long CFA, $\geq \mathrm{C} 16: 0$ ) were not affected with treatments (Table 5). However, only palmitic (C16:0) fatty acid was increased $(P=0.08)$ in the milk fat samples of treatment D $(31.38 \pm 1.8 \mathrm{~g} / 100 \mathrm{~g}$ fat $)$ as compared to treatments A $(25.76 \pm 0.55 \mathrm{~g} / 100 \mathrm{~g}$ fat $), \quad B$ $(28.17 \pm 1.18 \mathrm{~g} / 100 \mathrm{~g}$ fat $)$ and $\mathrm{C}(28.37 \pm 1.67$ $\mathrm{g} / 100 \mathrm{~g}$ fat).

Table 5: Saturated milk fatty acids (g/100g fat) in Harri ewes fed on four different diets (A, B, C, and D) during lactation. (means \pm SE).

\begin{tabular}{|c|c|c|c|c|c|}
\hline \multirow{2}{*}{ Fatty acids } & \multicolumn{4}{|c|}{ Treatments } & \multirow{2}{*}{$P$-value } \\
\hline & A & $\mathrm{B}$ & $\mathrm{C}$ & $\mathrm{D}$ & \\
\hline C6:0 & $1.34 \pm 1.34$ & $0.73 \pm 0.63$ & $0.89 \pm 0.88$ & $0.81 \pm 0.25$ & 0.959 \\
\hline C8:0 & $4.18 \pm 0.86$ & $3.57 \pm 0.84$ & $4.74 \pm 0.67$ & $3.0 \pm 0.67$ & 0.443 \\
\hline C10:0 & $8.14 \pm 0.83$ & $7.72 \pm 2.05$ & $7.91 \pm 1.37$ & $4.99 \pm 1.07$ & 0.385 \\
\hline C12:0 & $4.57 \pm 0.32$ & $4.13 \pm 0.99$ & $4.57 \pm 0.45$ & $5.22 \pm 2.19$ & 0.938 \\
\hline C14:0 & $9.06 \pm 0.51$ & $9.7 \pm 1.63$ & $9.87 \pm 0.14$ & $7.13 \pm 1.91$ & 0.443 \\
\hline C15:0 & $0.80 \pm 0.15$ & $0.67 \pm 0.1$ & $0.96 \pm 0.1$ & $0.86 \pm 0.11$ & 0.405 \\
\hline C16:0 & $25.76 \pm 0.55^{\mathrm{b}}$ & $28.17 \pm 1.18^{\mathrm{ab}}$ & $28.37 \pm 1.67^{\mathrm{ab}}$ & $31.38 \pm 1.8^{\mathrm{a}}$ & 0.08 \\
\hline C17:0 & $0.69 \pm 0.03$ & $0.64 \pm 0.04$ & $0.7 \pm 0.05$ & $0.71 \pm 0.03$ & 0.630 \\
\hline C18:0 & $12.66 \pm 1.0$ & $14.93 \pm 2.39$ & $12.16 \pm 0.81$ & $11.97 \pm .56$ & 0.438 \\
\hline C20:0 & $0.06 \pm 0.06$ & $5.2 \pm 0.15$ & $0.14 \pm 0.14$ & $0.09 \pm 0.09$ & 0.425 \\
\hline Total SATFA & $67.25 \pm 1.37$ & $73.13 \pm 8.92$ & $70.29 \pm 1.18$ & $65.77 \pm 2.61$ & 0.702 \\
\hline Short CFA & $13.66 \pm 1.95$ & $12.03 \pm 3.07$ & $13.53 \pm 2.23$ & $8.8 \pm 1.36$ & 0.417 \\
\hline Medium CFA & $15.33 \pm 0.41$ & $14.63 \pm 2.66$ & $16.14 \pm 0.52$ & $13.84 \pm 0.77$ & 0.708 \\
\hline Long CFA & $71.02 \pm 1.94$ & $75.67 \pm 5.26$ & $70.33 \pm 231$ & $77.74 \pm 2.05$ & 0.331 \\
\hline
\end{tabular}

A= 80:20; B=60:40; C=40:60; D=20:80 (C:R); C6:0 Caproic; C8:0 Caprylic; C10:0 Capric; C12:0 Lauric; C14:0 Myristic; C15:0 Pentadecylic; C16:0 Palmitic; C17:0 Margaric; C18:0 Stearic; C20:0 Arachidic; Total SATFA: total saturated fatty acids (C6:0-C20:0); Short CFA: short chain fatty acids (C6:0- C10:0); Medium CFA: medium chain fatty acids (C12:0 - C15:0); Long CFA: long chain fatty acids ( $\geq$ C16:0). 


\section{Discussion}

In the current study ewes were at their mature body weight and were lactating. It is apparent the ewes in groups A and B (80:20 and 60:40 $\mathrm{C}: \mathrm{R}$, respectively) suffered less body weight loss due to lactation compared to groups C and D (40:60 and 20:80 C:R, respectively). Birth weight and weaning weight of lambs born for these ewes fed on the four experimental diets was not different. Therefore, one can conclude that altered concentrate to roughage ratio had no effect on overall body weight of ewes after parturition and on their weaned lambs as well. Helal et al. (2011) reported that buffalo calves fed 100\% concentrate feed mixture with rice straw ad lib gained more body weight than calves fed $85 \%$ concentrate mixture, however feed conversion ratio was improved in calves fed on $70 \%$ concentrate mixture compared to other groups. Sultana et al. (2012) reported that growth rate did not differ significantly between groups of goats fed on different roughage to concentrate ratios. However, they reported that growth rate was increased with increased ratio of concentrate in the diet. Others (Kochapakdee et al., 1994) reported that female goats receiving concentrate diet $(0.8 \%$ bwt $)$ gained more weight than goats receiving no concentrates supplementation.

Ewes that received the highest roughage ratio $(80 \%$, group D) had greater daily milk yield compared to other groups. Percentages of milk fat, solids not fat (SNF), protein, lactose and minerals were not different among groups. However, milk fat yield was high in groups A and D. Group D had consistent increased yield of SNF, protein, lactose and minerals compared to other groups. This elevation milk fat yield in group D is possibly due to increased overall daily milk yield due to consumption of high roughage ratio $(80 \%)$ diet. The high roughage content is associated with increased fiber intake and improved rumen fermentation in the rumen and more production of milk precursors such as VFA.

Sanz Sapelayo et al. (2007) reported that the level of energy intake is positively related with the quantity and negatively with the fat content of sheep milk. In particular, a level of concentrate exceeding $60 \%$ dry matter is known to have a negative effect on the fat content (Martini et al., 2010). In the current study, The diet containing highest ratio of roughage $(\mathrm{D}, 80 \%$ roughage: $20 \%$ concentrate) produced greater milk yield, however all milk composition parameters of fat, SNF, protein, lactose and minerals percentages ( $\%$ ) were not affected by changing roughage to concentrate ratio. In the meantime, feeding low roughage to concentrate ratio ( $\operatorname{diet} \mathrm{A})$ is associate with increased intake of non-structural carbohydrate, which then lead to a decrease in the production of acetate and butyrate in the rumen due to rapid degradation of these noon-structural carbohydrates (Caja and Boquier, 2000). In cows, Sterk, et al. (2011) reported that shifting from a high forage $(65: 35 \mathrm{~F}: \mathrm{C})$ to a high concentrate (35: $65 \mathrm{~F}: \mathrm{C})$ diet increased dry matter intake and milk yield in dairy cows. The higher dry matter intake with high concentrate diets is associated with a lower dietary NDF content as suggested by Allen (2000). The observed increase in milk yield with high concentrate could be explained by a greater intake of dry matter, with higher nutrient density. However, such effect was not seen in the current study where the High concentrate diet (A) produced less milk yield than high roughage diet (D). This could be due to the higher nutritive value of the alfalfa hay as compared to the concentrate mixture.

Excessively high ratios of concentrates can reduce the intake of fiber and therefore reduce chewing times and rumen $\mathrm{pH}$. This can depress milk production and reduce the concentration of fat in milk (Oddy, 1978; Chiofalo, et al. 1993) probably because they cause rumen acidosis (Plaizier, et al. 2008). 
This can explain reduced milk yield in high concentrate $(80 \%)$ diet (A) compared to low concentrate $(20 \%)$ diet (D) in the current study. However, milk fat percentages were not affected by levels of concentrates in the diet in contrary to the former reports. In contrary, high roughage to concentrate ratio leads to an increase in the production of acetate by the celluletic bacteria in the rumen (Chesson and Forsberg, 1997), that can be used as a precursor for the synthesis of fat in the mammary gland.

Ewes receiving rations $A(80: 20 \mathrm{C}: \mathrm{R})$ and D (20:80 C:R) diets produced more milk fat $\%$ than groups $B(60: 40 \mathrm{C}: \mathrm{R})$ and $\mathrm{C}(40: 60 \mathrm{C}: \mathrm{R})$ receiving intermediate roughage to concentrate ratios. Results of Robinson et al. (1979) and Pulina et al. (1995) showed that milk yield and concentration of milk fat can be increased by increasing the protein content of the diet. Milk production parameters varied according to nutrient composition of feeds during lactation. Robinson, et al. (1979) found a slight increase in milk protein in ewes fed fishmeal, when compared with those fed soybean or peanuts protein supplements. Effects of fishmeal was attributed to an increase in the amount and profile of amino acids absorbed in the small intestine and that are available for milk synthesis.

Treacher (1989) documented 600 to 940 $\mathrm{ml} / \mathrm{d}$ improvements in milk yield with fish and blood meal supplementation of forage-fed ewes. Cannas (1995) observed that in sheep fed hay and concentrates, for a given concentration of NDF, a reduction in the particle size of hay resulted in a reduction in chewing time and an increase in feed intake. As a result the digestibility of dry matter and Neutral detergent Fiber decreased, but the amount digested per day was not affected. Consequently, there was an increase in milk yield and milk protein yield. Such increase in the yield of milk protein was found in group D (high roughage, $80 \%$ ) in the current study but the increase in milk protein yield could be due to increased milk yield rather than protein content of rations.

Saliba, et al. (2014) reported that high concentrate diet provided more starch content resulting in increased milk protein yield. Similar reports were reported by Sterk, et al. (2011) when supplied starch, a glycogenic precursor which has been shown to be correlated with increased milk protein synthesis. Similar results were reviewed by Emery (1978) reporting a positive correlation between milk protein and energy intake when concentrate was substituted for forages. Further, Robinson et al. (1979) and Pulina et al. (1995) have shown that milk yield and concentration of milk fat can be increased by increasing the protein content of the diet.

A tendency for a higher fat yield was observed with high concentrate diets (Saliba et al., 2014), which was consistent with the present data where high concentrate diet (A) produced significantly more milk fat yield compared to diets $\mathrm{B}$ and $\mathrm{C}$ not $\mathrm{D}$ diet. However, the current findings are contrary to those reported by Sterk, et al. (2011) who reported lower milk fat content when feeding high concentrate diets.

Roughage material (alfalfa hay) used in the current study was found to be high in its content of crude protein and provided high quality crude protein in addition to the high fiber fraction. So, diet D $(20: 80 \quad \mathrm{C}: \mathrm{R})$ containing $80 \%$ roughage is not expected to be deficient in CP content if compared to diet A (80:20 C:R) per se but the higher ratio of fibers is what distinguished that diet from other diets. It seems the rumen fermentation appeared to have been improved in groups A and $\mathrm{D}$ that were either high in concentrate ratio $(80 \%$, group A) or high in roughage ratio $(80 \%$, group D). Intermediate ratios of concentrate and roughage did not support optimal rumen fermentation performance reflected on milk yield and milk composition. 
The decrease in myristic (C14:0, 7.13\%) fatty acid in group D (80:20 F:C), would seem to have positive effects on human health. Martini et al. (2010) also observed decreased values of some medium chain fatty acids viz. C12:0 (14.89\%) and C14:0 (4.03\%) with the increase in roughage level in the diet of lactating ewes. On the other hand, an inverse effect was observed in relation to the oleic (C18:1, 28.03\%), linoleic (C18:2, 3.15\%), acids, which increased with the level of increased roughage (diet D, 20:80 C:R). Similar data were reported by Beyero, et al. (2015) in lactating cows. Higher percentages of palmitic (C16:0, 31.4\%) fatty acid do not appear to be favorable, since these fatty acids are have hyper cholesterolemic properties (Chiofalo et al., 2004). Similar trend was reported by Martini et al. (2010) in ewes fed on high forage to concentrate rations. Also Beyero et al. (2015) reported that as the dietary roughage proportion increased there was a significant reduction in the concentration (g/100g fat) of C10:0, C12:0 and C14:0 fatty acids.

Total long chain fatty acids (TLCFA, $77.7 \%$ ), monounsaturated fatty acids (MUFA, $29.75 \%$ ) and polyunsaturated fatty acids (PUFA, 4.49\%) increased with the increased proportion of roughage in the diet (Beyero et al., 2015). These finding are found to be in accordance with our findings in current study.

The lower percentage of short chain fatty acids in group D (8.8 g/100g fat) though not significant could be due to initial inhibition of de novo synthesis of the fatty acids in the mammary glands (Pérez Alba, 1997). An inverse trend was observed in the high concentrate diet A ( $80 \%$ concentrate) where short and medium chain fatty acids were increased. Further, due to this effect on de novo synthesis of short chain fatty acids, an alternate increase in the proportion of long chain fatty acids was seen in group D (high forage diet). Ewes from groups A (high C) and $\mathrm{D}$ (high R) had significant increase in the proportions of $\mathrm{C} 18: 2 \mathrm{c}$ and poly unsaturated fatty acids (PUFA) as compared to those of groups $\mathrm{B}$ and $\mathrm{C}$.

Polyunsaturated fatty acids are not synthesized by the tissue of ruminants, so their concentration in the milk strictly depends on the amount of the fat absorbed in the intestines and, therefore, on the amounts released in the rumen. Therefore, the increase in the roughage level proportionally decreases the concentrate contents and hence the availability of unsaturated fatty acids to be used by the mammary gland in the synthesis of milk lipids (Grummer, 1991; Chilliard et al., 2001 and Mesquita et al., 2008). Dairy cows on herbagebased diets derive fatty acids for milk fat synthesis from the diet and rumen microorganisms $(400-450 \mathrm{~g} / \mathrm{kg})$, from adipose tissues $(<100 \mathrm{~g} / \mathrm{kg})$, and from de novo biosynthesis in the mammary gland (about 500 $\mathrm{g} / \mathrm{kg}$ ) (Kalač and Samkova, 2010). The relative contributions of these fatty acids (FA) sources to milk fat production are highly dependent upon feed intake, and diet composition. High intake of concentrate diet is associated with a higher level of de novo synthesis resulting in more saturated milk fat. In contrast, higher intakes of PUFAs from forage result in higher concentrations of oleic acid, in milk fat (Walker et al., 2004).

\section{Conclusions}

It can be concluded that nutrition of sheep and formulation of their diet is greatly dependent on the physiological status of animals and hence their physiological requirements. Lactating ewes' rations should include adequate ratio of roughage to increase milk yield and improve milk fat composition and as a result improve lambs survival and growth weight. 


\section{References}

Allen, M. S. (2000) Effects of diet on short-term regulation of feed intake by lactating dairy cattle, J. Dairy Sci., 83: 1598-1624.

AOAC, (2006) Official Methods of Analysis of AOAC International (2000), $20^{\text {th }}$ ed. AOAC International, Arlington, VA, USA.

Beyero, N., Kapoor, V. and Tewatia, B.S. (2015) Effect of different Roughage: Concentrate Ratio on Milk Yield and Its Fatty Acid Profile in Dairy Cows, Journal of Biology, Agriculture and Healthcare, 5: 176-185.

Broster, W.B., Sutton, J.D. and Bines, J.A. (1979) Concentrate: forage ratios for high yielding dairy cows In: Recent Advances in animal Nutrition - 1978 pp: 99-126, Baa W. Haresign and D. Lewis, Butterworths London.

Caja, G. and Bocquier, F. (2000) Effects of nutrition on the composition of sheep's milk. Cahiers Options éditerranéennes, 74: 59-74.

Cannas, A., Pes, A. and Pulina, G. (1995) Effect of dietary energy and protein concentration on milk urea content in dairy ewes, Annual Meeting ADSA, Ithaca, New York, 25-28 June, J. Dairy Sci., 78, Suppl., 277.

Chesson, A. and Forsberg, C. W. (1997) Polysaccharide degradation by rumen microorganisms, In: The Rumen Microbial Ecosystem, (Ed.) P. N. Hobson and C. S. Stewart, Elsevier Science Publishers Ltd., London, UK, pp: 329-381.

Chilliard, Y., Ferlay, A. and Doreau, M. (2001) Contrôle de la qualité nutritionnelle des matières grasses du lait par l'alimentation des vaches laitières: acides gras trans, polyinsaturés, acide linoléique conjugué. INRA Productions Animales, 14: 323-335.

Chiofalo B., Liotta, L., Zumbo, A. and Chiofalo, V. (2004) Administration of olive cake for ewes feeling: effects on saturated, polyunsaturated, trans and conjugated fatty acids, Annales de Zootechnie, 49: 181-205.

Chiofalo, V., Micari, P., Savoini, G., Zumbo, A., Bontempo, V. and Ziino, M. (1993) Impiego di differenti fonti energetiche per l'alimentazione della pecora, effetti sulle caratteristiche quanti-qualitative nel latte (Use of different energy sources to feed sheep, effects on milk quantity and quality). In 'Proceedings of the $10^{\text {th }}$ Congress of the National Associazione Scientifica Produzione Animale, pp: 339-44. (Auenue Media Editrice, Bologna, Italy).

Coni, E., Bocca, A. and Caroli, S. (1999) Minor and trace element content of two typical itallian sheep dairy products, J. Dairy Res., 66, 589.

Emery, R.S. (1978) Feeding for increased milk protein, Journal of Dairy Science, 61: 825-828.

Grummer, R. R. (1991) Effect of feed on the composition on milk fat, J. Dairy Sci., 74: 3244-3257.

Helal, A., Puchala, R., Detweiler, G.D., Gipson, T.A., Sahlu, T. and Goetsch, A.L. (2011) Effects of restricted feed intake on energy expenditure by different goat breeds, J. Anim. Sci., 89: 4175-4187.
Jandal, J.M. (1996) Studies on dried fermented dairy products prepared from sheep milk, Small Ruminant Research, 21 (3): 217-220.

Kalač, P. and Samkova, E. (2010) The effects of feeding various forages on fatty acid composition of bovine milk fat. Review Article, Czech J. Anim. Sci., 55 (12): 521-537.

Kochapakdee S., Pralomkarn W., Saithanoo A., Lawpetchara A. and Norton B. W. (1994) Grazing management studies with Thai goats. II Reproductive performances of different genotypes of does grazing improved pasture with or without concentrate supplementation, Asian-australasian Journal of Animal Science, 7: 563-570.

Martini, M., Liponi, G. B., and Salari, F. (2010) Effect of forage: concentrate ratio on the quality of ewe's milk, especially on milk fat globules characteristics and fatty acids composition, The Journal of Dairy Research, 77 (2): $239-44$.

Mesquita, Í. V. U., Roberto, G. C., Rita de Cássia, R. E. Q., Ariosvaldo, N. M. and Alexandre, R. P. S. (2008) Profile of milk fatty acids from Moxoto goats fed with different levels of Manicoba (Manihot Glaziovii Muel Arg.) silage, Brazil. Archives Biol. and Technol., 51 (6): 1163-1169.

Molik, E., Zieba, D.A, Misztal, T., Romanowicz, K., Wszola, M., Wierzchos, E. and Nowakowski, M. (2008) The role of orexin A in the control of prolactin and growth hormone secretions in sheep - in vitro study, Journal of Physiology and Pharmacology, 59: 91-100.

NRC. (1985) Nutrient Requirements of Sheep, $6^{\text {th }}$ ed. National Academy Press. Washington, DC.

Oddy, V.H. (1978) Milk production in ewes fed high grain diets, Proc. Austral. Soc. Anim. Product., 12, 145.

Park, Y.W., Juarez, M., Ramos, M. and Haenlein, G.F.W. (2007) Physico-chemical characteristics of goat and sheep milk, Small Rum Res, 68: 88-113.

Pearson, S. (1981) Chemical Analysis of Foods, Eighth Edition.

Pérez Alba L.M., De Souza S., Pérez M., Martínez A. and Fernández G. (1997) Calcium soaps of olive fatty acids in the diets of Manchega dairy ewes: Effects on digestibility and production, J. Dairy Sci., 80: 33163324.

Plaizier, J. C., Krause, D. O., Gozho, G. N. and McBride, B. W. (2008) Subacute ruminal acidosis in dairy cows: The physiological causes, incidence and consequences, Veterinary Journal, 176 (1): 21-31.

Pulina G., Cannas A., Rassu S.P.G. and Rossi G. (1995). Effect of fiber and protein content of a complete pelleted feed on lactating dairy ewes, Agricoltura Mediterranea, 125: 115-20.

Radwan, S.S. (1978) Coupling of two dimensional thin layer chromatography with GC for the quantitative analysis of lipid classes and their constituents fatty acids, $J$. Chrom. Science, 16: 538-542.

Robinson J.J., Mc Hattie I., Calderon-Cortes J.F. and Thompson J.L. (1979) Further studies on the 
response of lactating ewes to dietary protein, Anim. Prod., 29: 257-269.

Saliba, L., Gervais, R., Lebeuf, Y., Vuillemard, J.C., Fortin, J. and Chouinard, P. Y. (2014) Effect of feeding linseed oil in diets differing in forage to concentrate ratio: 2. Milk lactone profile, Journal of Dairy Research, 81 (01): 91-97.

Sanz Sampelayo, M. R., Chilliard, Y., Schmidely, P. and Boza, J. (2007) Influence of type of diet on the fat constituents of goat and sheep milk, Small Ruminant Res., 68: 4263.

SAS, (2002) SAS users guide Statistical Analyses Systems Institute, Cary, USA. pp: 549-640.

Sterk A., Johansson B.E.O., Taweel H.Z.H., Murphy M., van Vuuren A.M., Hendriks W.H. and Dijkstra J. (2011) Effects of forage type, forage to concentrate ratio, and crushed linseed supplementation on milk fatty acid profile in lactating dairy cows, Journal of Dairy Science, 94: 6078-6091.
Sultana, S., Khan, M. J., Hassan, M. R., and Khondoker, M. A. M. Y. (2012) Effects of concentrate supplementation on growth, reproduction and milk yield of Black Bengal goats (Capra hircus), 29: 7-16.

Treacher T.T. (1989) Nutrition of the dairy ewe. In: North American Dairy Sheep Symposium. W.J. Boyland (Ed.). University of Minnesota, St-Paul. p. 45-55.

Van Soest, P. J., Robertson, J. B. and Lewis, B. A. (1991) Methods for dietary fibre, neutral detergent fibre and nonstarch polysaccharides in relation to animal nutrition, J. Dairy Sci., 74: 3583-3597.

Walker, G. P., Dunshea, F. R. and Doyle, P. T. (2004). Effects of nutrition on the production and composition of milk fat and protein: Review Article, Aust. J. Agri. Res., 55: 1009-1028. 


\section{إنتاج اللبن وتركيبه وتأثثر بالتعديلات الغذائية}

\section{سمير عطية نقادي، وهاني محمد باعقيل، وإيمان علي الوكيل *}

قسم زراعة المناطق الجافة؛ كلية الأرصاد والبيئة وزراعة المناطق الجافة؛ جامعة الملك عبدالعزبز ، جدة، المدلكة العربية السعودية، و** قسم الإنتاج الحبوانسي والسدكي؛ كلية الزراعة؛ جامعة الإسكندربة، الإسكندرية، جمهوربية مصر العربية

الهستخلص. أجريت هذه الدراسة لتقدير إنتاج اللبن وتركيبه الكيماوي ومحتواه من الأحماض الدهنية في النعاج الحري الحلابة (عدد ؟r) والمغذاة على علائق متباينة في نسبة المادة المالئة إلى المادة المركزة

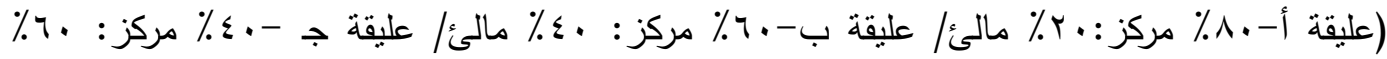

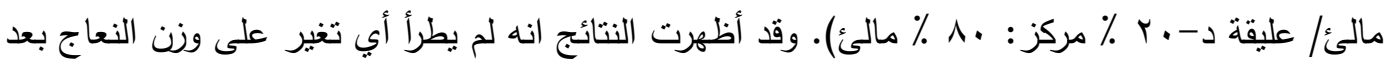

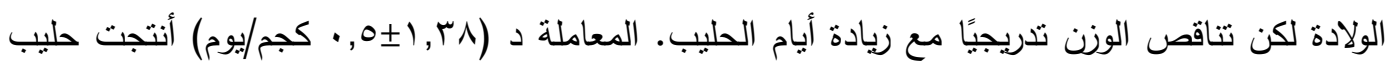

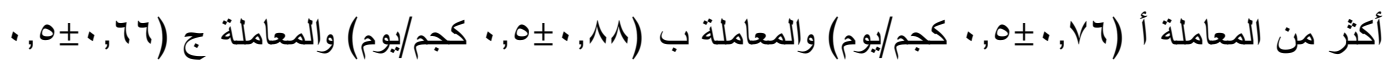
كجم/يوم). محصول كل من الدهن والجوامد الصلبة غير الدهنية والبروتين واللاكتوز والمعادن كان أعلى

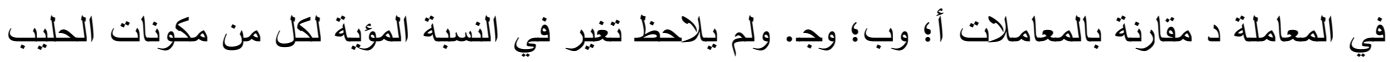
من الدهن والجوامد الصلبة غير الدهنية والبروتين واللاكتوز والمعادن. وارتفع محتوى دهن اللبن من

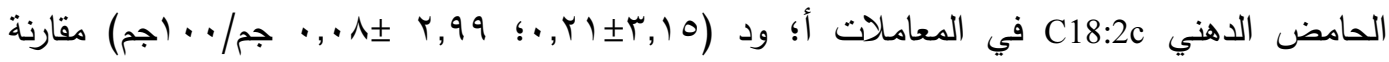

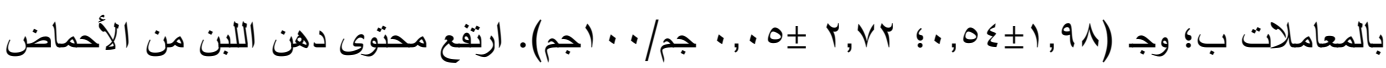

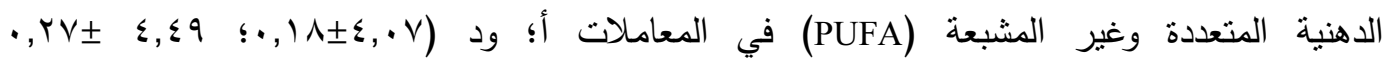

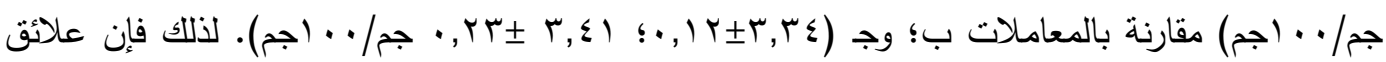
النعاج الحلابة يجب أن تحتوي على نسبة كافية من الألياف لزيادة إنتاج الحليب، ولتحسين محتوى دهن اللبن من الأحماض الدهنية غير المشبعة. الكلمات الدالة : أغنام؛ مادة مركزة: مادة مالئة؛ التغذية؛ إنتاج اللبن؛ الأحماض الدهنية. 